\title{
COMPULSORY MOTOR VEHICLE LIABILITY INSURANCE IN MASSACHUSETTS
}

\author{
RALPH H. BLANCHARD*
}

Discussion of the problem of security for persons injured in automobile accidents in Massachusetts resulted, in r9r9, in a legislative resolve directing the Attorney General and the Commissioner of Insurance of the state to inquire into the subject matter of two bills introduced in that year. These officials reported in January, I920 ${ }^{1}$ that the bills, which required every registrant of a motor vehicle to give evidence of liability insurance or of a bond covering his financial responsibility, were "drawn upon the theory that the State can and ought to require every person who operates an automobile to furnish protection for the public against the injuries which they may cause." They also considered the feasibility of a plan analogous to workmen's compensation but reported that "The proposition of replacing common law liability with a measured system of benefits is in our opinion an interesting possibility, but no more than that." They recommended the enactment of a law providing for compulsory liability insurance, stating that they did "not believe a State insurance company would furnish the best method of providing the insurance."

No law on the subject having been enacted, a commission was appointed under a resolve of the year Ig21. This commission considered the compulsory insurance and compensation plans, and the suggestion that an injured person might be given a lien on the automobile causing the injury. After commenting adversely on the com-

- A.B., rgr1, A.M., 19r2, Dartmouth; Ph.D., 1916, University of Pennsylvania. Professor of Insurance, Columbia University. Fellow and Vice-President, Casualty Actuarial Saciety. Fellow, Insurance Institute of America. President, American Association of University Teachers of Insurance. Consultant, Social Security Board. Editor, McGraw-Hill Insurance Series. Author, Liability and Compensation Instrance (1917), Workmen's Compensation in the United States (1926) and numerous articles on insurance subjects.

An exhaustive study of the operation of the Act is being made by Mr. Merwyn A. Kraft for the Bureau for Street Traffic Research of Harvard University. This study will probably be published later this year and will contain detailed information on many points which could not be treated at length here. Mr. Kraft has generously permitted me to examine his outline of the legislative history of the Act and to use certain of his accident figures.

I am indebted to W. N. Magoun, Manager of the Massachusetts Automobile Rating and Accident Prevention Bureau, E. S. Cogswell, First Deputy Commissioner of Insurance of Massachusetts, Gay Gleason, Counsel of the Employers' Liability Assurance Corporation, Ltd., E. W. Sawyer, Assistant General Counsel of the Liberty Mutual Insurance Company, the National Bureau of Casualty and Surety Underwriters, the National Association of Mutual Casualty Companies, and to many others for their assistance in the preparation of this article.

${ }^{1}$ Mass. Senate No. 322 . 
pensation proposal, the commission closed its report with the following statement: "Inasmuch as the proposition for compulsory insurance has been previously rejected by the General Court, and in view of the fact above stated that compulsory insurance might result in increasing the number of injuries, a bill is reported designed to establish a lien as suggested."1" The bill was not enacted.

In 1924 a Joint Special Legislative Committee (the Haigis Committee) was appointed under an order of the General Court to make a broad survey of motor vehicle problems. This committee reported in January, $1925^{1^{b}}$ in favor of compulsory liability insurance and submitted a bill which became the present compulsory law. One member of the committee filed a vigorous dissenting opinion in which he recommended the enactment of the lien law reported by the Ig2I commission.

\section{THE Act}

The Massachusetts Compulsory Automobile Liability Security Act requires that no motor vehicle ${ }^{2}$ or trailer shall be registered by the Registrar of Motor Vehicles unless the application is accompanied by a certificate of an insurance company authorized to transact such business in the Commonwealth, stating that it has issued an insurance policy or executed a binder on the vehicle providing bodily injury liability insurance with limits of $\$ 5,000 / \$ 10,000.4$

Non-residents may operate motor vehicles on the ways of the Commonwealth for 30 days in any one year without complying with any formalities, if their home states give equally favorable privileges to residents of Massachusetts. After 30 days, they are permitted to operate only if they maintain in full force a policy of liability insurance equivalent to that required of registrants and on the authority of a permit from the Registrar. In practice, the Registrar requires a non-resident to make

1a Mass. Senate No. 285 (January, r922). $\quad{ }^{16}$ Mass. Senate No. 285.

${ }^{2}$ Mass. Laws I925, c. 346,3 MAss. ANn. Laws (r933) c. 90, $\$ 34 A-34 J$. In this article only the more significant provisions of the Act will be covered. For the complete text, see Laws Relative to Compulsory Automobile Liability Insurance, a pamphlet published by the Commonwealth. For a discussion of the constitutionality of the Act, see In re Opinion of Justices, 25I Mass. 569, I47 N. E. 681 (1925).

${ }^{3}$ Motor vehicles are defined as "automobiles, semi-trailer units, motor cycles and all other vehicles propelled by power other than muscular power, except railroad and railway cars, vehicles operated by the system known as trolley motor or trackless trolley under chapter one hundred and sixty-threc, and motor vehicles running only upon rails or tracks, road rollers, street sprinklers, snow loaders, power excavators, power graders and concrete mixers." 3 MAss. ANN. Laws (1933) c. 90, $\$ 1$, incorporated by reference in id., c. $90, \$ 34 \mathrm{~A}$.

\$5,000 on account of injuries to any one person; \$ro,000 on account of any one accident. Limits for school buses operated under contract with cities or towns are $\$ 5,000 / \$ 50,000$ (Mass. Acts 1932, c. 27r.) The Registrar may also accept a certificate stating that a bond guaranteeing payment of damages within the same limits has been executed by a surety company duly authorized, or the certificate of the Department of Public Works that the applicant has deposited $\$ 5,000$ in cash or securities as a guaranty of his ability to pay damages for bodily injury as defined in the law, but these alternatives are used only in a negligible number of cases. Exempt from these requirements are the following: Certain common carriers, certain corporations subject to the supervision and control of the Department of Public Utilitics, street railway companies under public control, and the Commonwealth, or any political subdivision thercof. Ambulances, fire engines and apparatus, police patrol wagons and other vehicles used by the police departments of any town or park board solely for its official business are also exempt from the requirements of the Act. 
application certifying to the maintenance of such insurance and issues a permit without further formality.

The compulsory coverage is applicable only to

liability to pay damages to others for bodily injuries, including death at any time resulting therefrom, or consequential damages consisting of expenses incurred by a husband, wife, parent or guardian for medical, nursing, hospital or surgical services in connection with or on account of such bodily injuries or death, sustained during the term of said policy by any person, other than a guest occupant of such motor vehicle or of any employee of the owner or registrant of such vehicle or of such other person responsible as aforesaid who is entitled to payments or benefits under the provisions of chapter one hundred fiftytwo, and arising out of the ownership, operation, maintenance, control or use upon the ways [public highways] of the commonwealth of such motor vehicle. ${ }^{5}$

If one desires to carry complete coverage, it is necessary also to buy insurance covering liability to: ( $\mathrm{I}$ ) Guest occupants upon the ways of Massachusetts; (2) Guest occupants in other states, and off the ways in Massachusetts; (3) Any person not included under the statutory coverage, nor under items ( $I$ ) and (2). These coverages are known respectively as "statutory," "guest occupant upon the ways of Massachusetts," "extraterritorial guest occupant," and "supplementary."6

The Act as it stands today is virtually the same as when it originally went into effect on January $\mathrm{x}$, I927, with two exceptions: Commencing with $\mathrm{r} 93 \mathrm{I}$, coverage of consequential damages was made compulsory, and commencing with r936, damages to guest occupants were eliminated from the compulsory coverage. T.wo attempts were made in 1925 to submit the Act to the voters by referendum. Both failed, one petition being withdrawn and the other not meeting the legal requirements.

Two laws closely related to the Act should be mentioned in passing. A law passed in $1932^{7}$ requires the Registrar to suspend the license to operate of a motorist who, after 60 days from the date of a judgment in an action for damage to property, has failed to satsify it. In I935, in the case of Gallagher $v$. Wheeler, ${ }^{8}$ the Supreme Judicial Court decided that, under the "rule-of-the-road law,", an operator is liable for injuries resulting from the violation of certain rules of the road, regardless of negligence. As a résult of this decision, the insurance carriers fixed an annual premium of $\$ 6.5^{\circ}$ per private passenger car for coverage of liability for damages on the ways of the state resulting from the rule-of-the-road law. Varying charges were made for other types of motor vehicle. A law ${ }^{10}$ approved February I3, I936 eliminated liability from this source and made this coverage unnecessary.

In January, I930, a special commission, consisting of four members of the legislature and three appointees of the governor, appointed in accordance with a resolu-

5Mass. Ann. Laws (1935 Supp.) c. 90, \$34A.

- Previous to 1936 , guest occupants on the ways of Massachusetts were included in the statutory coverage. Full coverage then consisted of "statutory" and "extraterritorial:" During the period 1927 to 1935, inclusive, an average of 97.7 per cent of the cars were written for full coverage.

${ }^{7}$ Mass. ANn. Laws (I933) c. 90, \$22A.

${ }^{8}$ rg8 N. E. 89 1 (Mass. r $9 z^{r}$ ).

${ }^{\circ}$ Mass. Ann. Laws (1933) c. 89, \$5.

${ }^{10}$ Mass. Acts, I936, c. 49. 
tion of the legislature, made an exhaustive report ${ }^{11}$ on the operation of the law with recommendations for its improvement. The Commission stated that it did not "believe in giving up the substance of the experiment which this Commonwealth has found courage to try." It did, however, "recommend some striking changes in the existing law."

As a result of the report of this commission and of the controversy over the rates of premium charged for insurance under the Act, an extra session of the legislature was held in the autumn of $193 \mathrm{I}$ for the express purpose of amending the Act. Nothing was accomplished, although a large number of bills were introduced. Further efforts to amend the law during the regular session in 1932 had scant results.

The legislative history of the Act shows that its repeal or drastic amendment is highly improbable.

\section{The Insurance Contract}

The contract of bodily injury liability insurance in use in Massachusetts for statutory coverage differs considerably from that now standard elsewhere. ${ }^{12}$ The differences flow naturally from the general or specific provisions of the law. ${ }^{13}$ Optional coverages are subject to most of the provisions of the national standard form. For purposes of convenience the statutory coverage and the optional coverages are combined in one policy.

In the "insuring agreements" the Act is cited, and the contract is specifically made an agreement to pay in accordance with the Act.

The statutory contract covers "consequential damages consisting of expenses incurred by a husband, a wife, parent or guardian for medical, nursing, hospital or surgical services in connection with or on account of such bodily injury or death," in addition to direct damages, and specifies that the injury or death must be "caused by ownership, operation, maintenance, control or use of the motor vehicle...." The standard contract includes "damages for care and loss of services" and covers injury or death "caused by accident and arising out of the ownership, maintenance, or use of the automobile." These variations in wording probably have little practical effect.

The word "insured" as used in the statutory contract includes not only the named insured "but also any other person responsible for the operation of the motor vehicle with the express or implied consent of the named insured." The standard contract is somewhat less broad, extending the term "insured" to cover "any person while using the automobile and any person or organization legally responsible for the use thereof, provided that the declared and actual use of the automobile is 'pleasure and

${ }^{2}$ Report of the Special Commission to Study Compulsory Motor Vehicle Liability Insurance and Related Matters. Mass. Senate No. 280, reprinted in (r930) I5 Mass. L. Q., No. 3.

${ }^{13}$ For the form of policy now generally used in other states see SAwYER, AutoMoBiLE LiABILITY INSURANCE, 288-298. In the remainder of this article, the term "statutory contract" will be used to designate that part of the Massachusetts policy providing statutory (compulsory) coverage; the tertn "standard contract," to designate the national standard contract. The statutory requirements controlling the statutory contract are contained in 5 MAss. ANN. LAws, (1933) c. I75, \$113A, and id. (1935 Supp.) 5113A.

Is Certain unimportant textual differences will not be considered. 
business' or 'commercial,' each as defined herein, and provided further that the actual use is with the permission of the named insured." It further limits this extension by excluding

(a) "any person or organization with respect to any loss against which he has other valid and collectible insurance"; (b) "any person or organization with respect to bodily injury to or death of any person who is a named insured"; (c) "any person or organization, or ... any agent or employee thereof, operating an automobile repair shop, public garage, sales agency, service station, or public parking place, with respect to any accident arising out of the operation thereof"; (d) "any employee of an insured with respect to any action brought against said employee because of bodily injury to or death of another employee of the same insured injured in the course of such employment in an accident arising out of the miaintenance or use of the automobile in the business of such insured."

An important provision of the statutory contract, no equivalent of which is found in the standard contract, reads as follows:

No statement made by the insured or on his behalf either in securing this policy or in securing registration of the motor vehicle, no violation of the terms of this policy and no act or default of the insured, either prior to or subsequent to the issuance of this policy shall operate to defeat or avoid this coverage so as to bar recovery by a judgment creditor proceeding in accordance with the Laws of the Commonwealth of Massachusetts. The terms of this policy shall remain in full force and effect, however, as binding between the insured and the company, and the insured agrees to reimburse the company. for any payment made by the company hereunder on account of any accident, claim or suit, involving a breach of the terms of this policy and for any payment the company would not have been obligated to make if the exclusions applicable to coverage $B$ were applicable to this coverage.

Both the statutory contract and the standard contract require the insured to give the insurer notice of the occurrence of an accident and to forward "every demand, notice, summons or other process received by him or his representative" in connection with a claim or suit. He must also coöperate with the insurer in its various activities incident to the adjustment of claims. Failure of the insured to conform to these requirements is a breach of the contract and relieves the insurer of its obligations to the insured. Under the standard contract the insurer is relieved of all obligations, but under the statutory contract it must pay any judgment for damages, regardless of the breach of the contract by the insured. The standard contract also does not apply:

(a) while the automobile is used in the business of demonstrating or testing, or as a public or livery conveyance, or for carrying persons for a consideration, or while rented under contract or leased, unless such use is specifically declared and described in this policy and premium charged therefor:

(b) while the automobile is used for the towing of any trailer not covered by like insurance in the company; or while any trailer covered by this policy is used with any automobile not covered by like insurance in the company;

(c) while the automobile is operated by any person under the age of fourteen years, or by any person in violation of any state, federal or provincial law as to age applicable 
to such person or to his occupation, or by any person in any prearranged race or competitive speed test;

(d) to any liability assumed by the insured under any contract or agreement; or to any accident which occurs after the transfer during the policy period of the interest of the named insured in the automobile, without the written consent of the company;

(e) to bodily injury to or death of any employee of the insured while engaged in the business of the insured, other than domestic employment, or in the operation, maintenance or repair of the automobile.

These exclusions are omitted from the statutory contract.

If the insurer is obliged, by reason of the operation of the statutory provisions, to make a payment which it would not have been obligated to make under these terms of the standard policy, it is entitled to reimbursement therefor by the insured. Such a right is not, of course, always enforcible.

Cancellation of the statutory coverage and of the optional coverages which may be written in connection with it may be effected, subject to the provisions of the law on appeals from cancellation, ${ }^{14}$ by either insurer or named insured,

upon written notice to the other stating the date, not less than fifteen days thereafter, when such cancellation shall be effective, provided, however, that if either the named insured or the company cancels and the named insured files with the Registrar of Motor Vehicles of Massachusetts a new certificate of insurance after the sending of the notice of cancellation by the company or after giving such notice to the company, and prior to the effective date thereof, this policy shall be terminated as of the date of filing of such certificate. Notice of cancellation of coverage A [statutory] shall be in such form as the Department of Public Works of Massachusetts may prescribe and copy thereof shall be sent concurrently to the Registrar of Motor Vehicles of Massachusetts. Notice of cancellation sent to the named insured by the company by registered mail, postage prepaid, with a return receipt requested at his address as stated in this policy shall be sufficient notice.

Cancellation of the standard contract may be effected by the insured at any time by written notice to the insurer and by the insurer at any time, not less than five days after mailing written notice to the insured.

The Massachusetts contract (statutory and all other coverages) is also terminated under the following conditions:

(I) Sale or transfer of the motor vehicle by the insured; ${ }^{15}$

(2) The surrender by the insured of his registration plates to the Registrar with a written statement that they are surrendered to cancel the registration and the contract;

(3) Upon filing a certificate of insurance with another insurer covering the motor vehicle;

(4) Ninety days after the death of the insured, if no legal representative of his estate has been appointed. ${ }^{16}$

(5) If the company ceases to be authorized to transact business in Massachusetts.

14 Infra, p. 55 x.

${ }^{25}$ There is no provision for assignment.

${ }^{10}$ The statutory and standard contracts differ somewhat as to the effect of the insured's death or bankruptcy. The former, which is the more liberal, provides as follows: "If, within the policy period, 
Termination of the contract except by cancellation by the insurer, by expiration, or by the insurer ceasing to be authorized calls for adjustment of the earned premium on a short-rate basis, ${ }^{17}$ subject to the right of the insurer to retain specified minimum premiums. Provision is made for the return of unearned premium if the insured "has paid the premium on the policy to the company, or to its agent who issued the policy, or to the duly licensed insurance broker, if any, by whom the policy was negotiated."

If the insured has other valid and collectible insurance covering his statutory obligation with an insurer authorized to transact casualty insurance in Massachusetts, each insurer will be liable only in the proportion which the limits of its liability bear to the total applicable limits. Under the standard contract this same principle is applied to all valid and collectible insurance carried by the named insured.

The statutory coverage does not apply to the injury to or death of any guest occupant of the motor vehicle. "Guest occupant" is defined as

any person, other than an employee of the owner or registrant of a motor vehicle or of a person responsible for its operation with the owner's or registrant's express or implied consent, being in or upon, entering or leaving the same, except a passenger for hire in the case of a motor vehicle registered as a taxicab or otherwise for carrying passengers for hire.

If optional coverages are desired they must be specifically included in the contract.18 If statutory and additional optional coverages are purchased the following provision is applicable:

If bodily injury occurs with respect to which insurance is afforded under coverage A, the insurance thereunder shall first be applied and the limits of liability thereunder shall first be fully exhausted before any of the limits of liability applicable to coverage B shall apply. The limits of liability applicable to coverage $A$ are included in the limits of liability applicable to coverage $B$, and are not in addition thereto. The limits of liability applicable to coverage B are applicable to coverage B in its entirety and are not applicable separately to the divisions thereof. ${ }^{19}$

In general, the provisions of the statutory contract which differ from the standard contract are designed to carry into effect the purposes of the Act. They result in a

the named insured shall die, or because of his insolvency or bankruptcy he shall lose his right to possession of the motor vehicle, this policy, unless canceled, shall cover (I) the legal representative of the named insured's estate as the named insured, and (2) in case of death, any person having proper temporary custody of the motor vehicle, as an insured, pending the appointment of such legal representative, but not for a period extending beyond ninety days after the death of the named insured."

The standard contract provides that if "the named insured shall die or be adjudged bankrupt or in. solvent within the policy period, this policy, unless canceled, shall, if written notice be given to the company within thirty days after the date of such death or adjudication, cover (I) the named insured's legal representative as the named insured, and (2) ... any person having proper temporary custody of the automobile, as an insured, until the appointment and qualification of such legal representative, but in no event for a period of more than thirty days after the date of such death or adjudication."

${ }^{17} \mathrm{~A}$ special short-rate table is applicable to all bodily injury liability coverage written for a period of less than one year.

${ }^{23}$ See supra, pp. 539 and 540.

${ }^{20}$ Coverage $A$ is statutory coverage; coverage $B$ is the combined optional coverages. 
contract considerably more liberal to insured and claimant than is the standard contract.

\section{Premium Rates}

The Act requires the Commissioner of Insurance annually to

fix and establish fair and reasonable classifications of risks and adequate, just, reasonable and non-discriminatory premium charges to be used and charged by companies in connection with the issue or execution of motor vehicle liability policies or bonds ${ }^{20}$

providing statutory coverage. $\mathrm{He}$ is also required to make rates for guest-occupant coverage on the ways of the state, though the parties to any policy or bond may mutually contract for the payment of a rate higher than that made by the Commissioner. No variations from rates for statutory coverage is permitted. The Commissioner must give due notice of the rates which he proposes to establish for each year and of a public hearing on them. A petition for review of the rates or classifications may be made to the Supreme Judicial Court, which shall accord it a "speedy and summary hearing on the merits." "The decision of the Court shall be final and conclusive on the parties."

Pursuant to these requirements and the Commissioner's authority to require insurers "to file with him such data, statistics, schedules or information as he may deem proper or necessary,"21 he promulgates a statistical plan each year. This plan embodies the rules in accordance with which the insurance carriers file data on their experience under the Act.

Previous to the effective date of the Act, the Massachusetts Automobile Rating and Accident Prevention Bureau was organized at the suggestion of the Commissioner. The Bureau, whose membership includes all carriers writing automobile liability insurance under the Act, compiles statistics, develops actuarial methods, and suggests classifications and rates of premium to the Commissioner. His representative occupies an office adjacent to the quarters of the Bureau, is in continuous contact with its operations, and has access to all data. The recommendations to the Commissioner, which are accompanied by the underlying data and an explanation of the methods employed in reaching them are in no way binding on him. The rates which he has established each year have been lower than those recommended; he has frequently set up different territorial groupings and at times has also established a different scheme of classification of motor vehicle risks.

The rates are made up of two principal parts; provision for the payment of losses and loading for expenses and profit. For the year x936, 64 per cent of the premium charge represents provision for losses, and $3^{6}$ per cent loading for expenses and profit. ${ }^{22}$ This loading is the same as that used for 1935 rates when it was made up of the following factors:

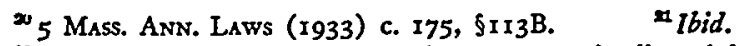

${ }^{22}$ An additional expense loading of 2.9 per cent is allowed for garages. 


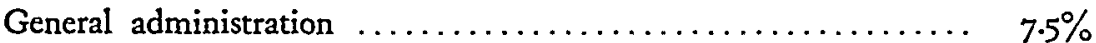

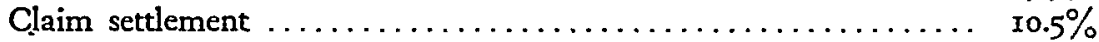

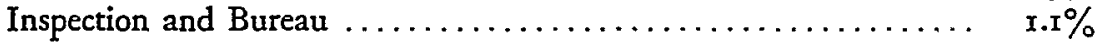

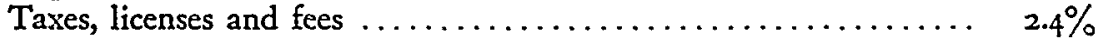

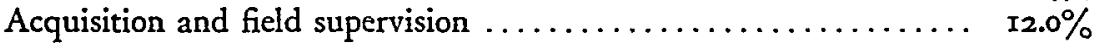

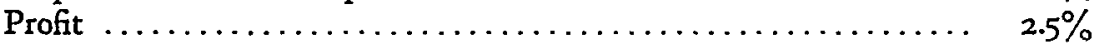

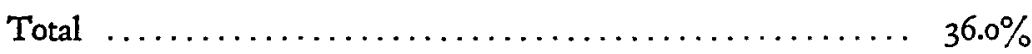

The principal point of difference between this loading allowance and that found in other states is in the item for acquisition which usually is 25 per cent.

The fixing of rates has been a source of unending controversy. Stock insurance companies have regularly protested their inadequacy and have made formal complaint at the public hearings before the Commissioner; representatives of high-rated communities have complained of injustice and have argued for average rates to be applied to the state as a whole; representatives of motor-vehicles owners' interests have demanded lower rates, often on the basis of the effect on their business; politicians have entered appearances to protest high rates with little basis except their desire to cater to their constituents. At one point the Commissioner of Insurance, Wesley E. Monk, resigned rather than accede to the demand of the Governor that he establish rates lower than he thought correct. He stated in a letter to the Governor that he considered it "neither right nor proper" to "attempt to solve a mathematical problem by the introduction of a factor of political expediency." The political factor has influenced the making of rates at all times, but that occasion was the only one on which it was blatantly injected into the situation. It has probably resulted in a conscious or unconscious resolving of all doubts in favor of methods which would produce the lower of two possible rate levels.

For the first two years of the Act, I927 and 1928, there was little basis for the calculation of rates. With the accumulation of experience, it became possible more nearly to relate rates to actual conditions. The relative rate levels for 1926 and for each succeeding year for the state as a whole are indicated by the following figures:

Index Numbers of Rate Level in Massachusetts for Bodily Injury Liability Insurance on Private Passenger Cars*

\begin{tabular}{|c|c|c|}
\hline 1926. & $\ldots \ldots \ldots \ldots, \mathrm{x} \cdot \mathrm{I} 28$ & I.316 \\
\hline 1.000 & $\ldots \ldots \ldots \ldots{ }^{1.225}$ & I. 356 \\
\hline & $\ldots \ldots \ldots r .33^{6}$ & $I$ \\
\hline $929 \ldots \ldots \ldots \ldots \ldots .1 .069$ & $1933 \ldots \ldots \ldots \ldots \ldots=1.309$ & \\
\hline
\end{tabular}

The level of rates established by the Commissioner for 1937 for statutory coverage is approximately 7 per cent below that of 1936 .

While rates have shown an increase of over $5^{\circ}$ per cent since the inception of the Act, this increase is not necessarily attributable to the Act. During the period 1927 to $\mathrm{I} 935$ while rates were increasing $5^{1.5}$ per cent in Massachusetts, they increased 27.6

- Rates for coverages equivalent to usual coverage in other states, i.e., statutory coverage plus optional coverages. 
per cent in the remainder of the country. But in individual states they increased by widely varying percentages: 1.6 in New York; 79.2 in California; 7.2 in Ohio; 7r.7 in Virginia; 2r.6 in Pennsylvania; 34.4 in Connecticut, and 6r.5 in New Jersey. Mere percentage figures mean little. They depend on the adequacy of rates in the year used as a base, on the action of state authorities, on considerations of business policy, as well as on the underlying experience of the carriers. Further there is no unassailable method of determining changes in level. These figures are informative but not highly significant.

Rates for individual cities or towns have shown wide variations between rg26 and 1937. They are shown in detail for selected localities in the following table:

Bodily Injury Liability Insurance Rates, Massachusetts, Private Passenger Cans (INCLUding EXtra-Territorial Coverage)

W Cars

\begin{tabular}{|c|c|c|c|c|c|c|c|c|c|c|c|c|}
\hline & 192 & 1927 & 1928 & 1929 & 1930 & 1931 & 1932 & 1933 & 1934 & 1935 & *1936 & *1937 \\
\hline 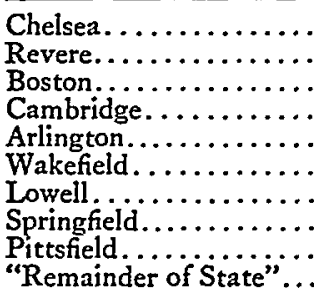 & $\begin{array}{l}41 \\
41 \\
41 \\
41 \\
41 \\
26 \\
26 \\
26 \\
19 \\
14\end{array}$ & $\begin{array}{l}31 \\
31 \\
31 \\
31 \\
31 \\
24 \\
24 \\
24 \\
18 \\
18\end{array}$ & \begin{tabular}{l|}
31 \\
31 \\
31 \\
31 \\
31 \\
24 \\
24 \\
24 \\
18 \\
18
\end{tabular} & $\begin{array}{l}49 \\
49 \\
49 \\
49 \\
33 \\
27 \\
27 \\
23 \\
16 \\
16\end{array}$ & $\begin{array}{l}67 \\
60 \\
51 \\
46 \\
34 \\
34 \\
26 \\
24 \\
18 \\
18\end{array}$ & $\begin{array}{l}67 \\
60 \\
56 \\
46 \\
35 \\
35 \\
28 \\
26 \\
19 \\
19\end{array}$ & $\begin{array}{l}90 \\
76 \\
64 \\
49 \\
37 \\
37 \\
40 \\
29 \\
19 \\
14\end{array}$ & $\begin{array}{l}83.50 \\
75.50 \\
62.50 \\
48.50 \\
37.50 \\
37.50 \\
39.50 \\
30.50 \\
20.50 \\
20.50\end{array}$ & $\begin{array}{l}80.50 \\
74.50 \\
65.50 \\
49.50 \\
38.50 \\
38.50 \\
39.50 \\
31.50 \\
21.50 \\
21.50\end{array}$ & $\begin{array}{l}76 \\
75 \\
65 \\
51 \\
40 \\
40 \\
39 \\
35 \\
23 \\
23\end{array}$ & $\begin{array}{l}78.15 \\
67.65 \\
67.65 \\
54.10 \\
44.45 \\
44.45 \\
44.45 \\
39.65 \\
27.50 \\
27.50\end{array}$ & $\begin{array}{l}70.00 \\
61.70 \\
61.70 \\
50.70 \\
42.60 \\
42.60 \\
42.60 \\
37.95 \\
25.80 \\
25.80\end{array}$ \\
\hline
\end{tabular}

$\mathrm{X}$ CARS

\begin{tabular}{|c|c|c|c|c|c|c|c|c|c|c|c|c|}
\hline 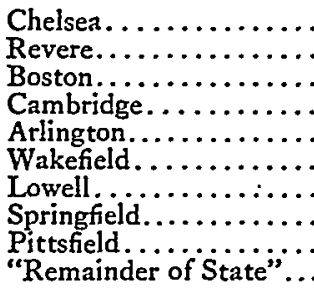 & $\begin{array}{l}50 \\
50 \\
50 \\
50 \\
50 \\
31 \\
31 \\
31 \\
23 \\
18\end{array}$ & $\begin{array}{l}39 \\
39 \\
39 \\
39 \\
39 \\
29 \\
29 \\
29 \\
22 \\
22\end{array}$ & $\begin{array}{l}39 \\
39 \\
39 \\
39 \\
39 \\
29 \\
29 \\
29 \\
22 \\
22\end{array}$ & $\begin{array}{l}49 \\
49 \\
49 \\
49 \\
33 \\
32 \\
32 \\
25 \\
23 \\
23\end{array}$ & $\begin{array}{l}70 \\
63 \\
56 \\
47 \\
36 \\
36 \\
31 \\
29 \\
23 \\
23\end{array}$ & $\begin{array}{l}71 \\
64 \\
61 \\
48 \\
41 \\
41 \\
34 \\
32 \\
27 \\
27\end{array}$ & $\begin{array}{l}96 \\
81 \\
69 \\
53 \\
40 \\
40 \\
44 \\
32 \\
25 \\
25\end{array}$ & $\begin{array}{l}88.50 \\
80.50 \\
66.50 \\
48.50 \\
37.50 \\
37.50 \\
39.50 \\
30.50 \\
22.50 \\
22.50\end{array}$ & $\begin{array}{l}80.50 \\
74.50 \\
65.50 \\
49.50 \\
38.50 \\
38.50 \\
39.50 \\
31.50 \\
21.50 \\
21.50\end{array}$ & $\begin{array}{l}76 \\
75 \\
65 \\
51 \\
40 \\
40 \\
39 \\
35 \\
23 \\
23\end{array}$ & $\begin{array}{l}78.15 \\
67.65 \\
67.65 \\
54.10 \\
44.45 \\
44.45 \\
44.45 \\
39.65 \\
27.50 \\
27.50\end{array}$ & $\begin{array}{l}70.00 \\
61.70 \\
61.70 \\
50.70 \\
42.60 \\
42.60 \\
42.60 \\
37.95 \\
25.80 \\
25.80\end{array}$ \\
\hline
\end{tabular}

Y CARS

\begin{tabular}{|c|c|c|c|c|c|c|c|c|c|c|c|c|}
\hline 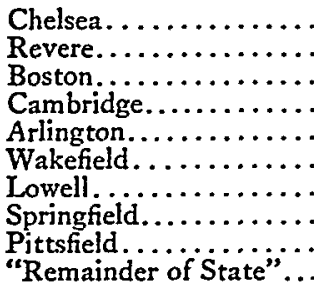 & $\begin{array}{l}61 \\
61 \\
61 \\
61 \\
61 \\
37 \\
37 \\
37 \\
28 \\
22\end{array}$ & $\begin{array}{l}47 \\
47 \\
47 \\
47 \\
47 \\
36 \\
36 \\
36 \\
27 \\
27\end{array}$ & $\begin{array}{l}47 \\
47 \\
47 \\
47 \\
47 \\
36 \\
36 \\
36 \\
27 \\
27\end{array}$ & $\begin{array}{l}64 \\
64 \\
64 \\
64 \\
40 \\
39 \\
39 \\
37 \\
30 \\
30\end{array}$ & $\begin{array}{l}83 \\
75 \\
62 \\
59 \\
44 \\
44 \\
38 \\
38 \\
29 \\
29\end{array}$ & $\begin{array}{l}85 \\
77 \\
71 \\
61 \\
49 \\
49 \\
41 \\
39 \\
32 \\
32\end{array}$ & $\begin{array}{l}119 \\
101 \\
72 \\
66 \\
50 \\
50 \\
54 \\
40 \\
32 \\
32\end{array}$ & $\begin{array}{l}93 \\
85 \\
70 \\
62 \\
49 \\
49 \\
50 \\
40 \\
31 \\
31\end{array}$ & $\begin{array}{l}87 \\
80 \\
71 \\
54 \\
47 \\
47 \\
49 \\
38 \\
29 \\
29\end{array}$ & $\begin{array}{l}82 \\
80 \\
70 \\
58 \\
46 \\
46 \\
45 \\
40 \\
28 \\
28\end{array}$ & $\begin{array}{l}82.80 \\
71.75 \\
71.75 \\
57.50 \\
47.35 \\
47.35 \\
47.35 \\
42.30 \\
30.85 \\
30.85\end{array}$ & $\begin{array}{l}76.30 \\
67.30 \\
67.30 \\
55.35 \\
46.65 \\
46.65 \\
46.65 \\
41.55 \\
30.45 \\
30.45\end{array}$ \\
\hline
\end{tabular}

-Including complete guest coverage and supplementary coverage. 1937 rates are based on the rates for ttatutory and guest coverage on the ways of Massachusetts as established by the Commissioner of Insurance. September 21 . 1936, and on rates for extraterritorial guest occupant and supplementary coverage as determined by the Bureau, August 13,1936 . A group of 42 stock companies has filed a petition in the Supreme Judicial Court for review of the statutory rates. 
Since the Act has resulted in insurance being placed on all cars registered in the state and since the experience of all carriers is compiled by the Bureau, it is possible to determine the probable losses for relatively small territories. Many of the changes in the rates for individual areas are due to the indications of a greater volume of data than would have been available if insurance had been voluntary, and if rates had been based on the experience of one class of carriers. While it would be incorrect to attribute changes in the level of rates for the state as a whole solely to the operations of the Act, it would be doubly so to hold the Act responsible for changes in rates for any territory, unless the connection could be established by other evidence than that of the change itself during the period for which the Act has been in force. Much has come to light which before was hidden. Rates in particular communities in Massachusetts are often compared with those in communities of the same size in other states for the purpose of determining the effect of the Act. Rates are a product of so many causes that it is incorrect to attribute differences to one factor without additional convincing evidence.

The insurance experience rather than the rates of premium charged is a far better indication of the results of conditions affecting automobile liability insurance, both in Massachusetts and elsewhere. Even this experience must be subject to qualifications, and it should be remembered that it is the outgrowth of a complex of influences in each state, some operating generally throughout the country, many peculiar to the state. Much fallacious reasoning of the post-hoc variety has been offered in explanation of changes in loss costs.

The following table indicates the relative increases in average loss cost experienced in Massachusetts and elsewhere: ${ }^{23}$

\section{Private Passenger Cars \\ Percentage Increases in Average Loss Cost}

1927-1934 (inclusive)

I. Massachusetts Statutory Coverage (Stock and Mutual) .............. 3I $^{\text {I }}$

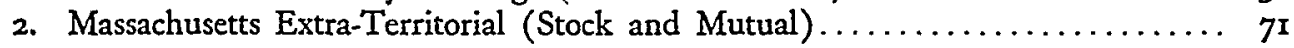

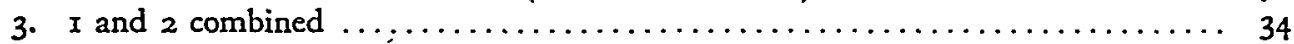

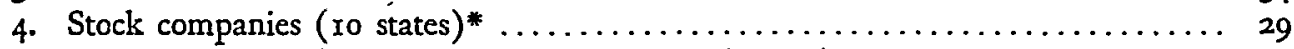

5. Stock companies (country-wide, except Massachusetts) ................ 29

1930-1934 (inclusive)

I. Massachusetts Statutory Coverage (Stock and Mutual) .............. II

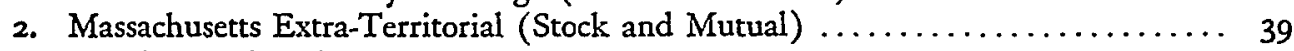

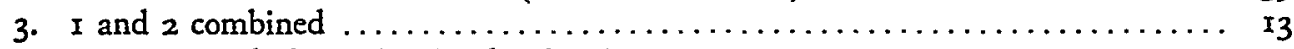

4. I2 states, excluding New York City**..................... II

- California, Connecticut, Illinois, Missouri, New Jersey, New York, Ohio, Pennsylvania, Virginia, and Wisconsin.

- Stock and Mutual Companies in New Hampshire, New York, North Carolina, and Virginia; Stock Companies only in California, Connecticut, Illinois, Missouri, New Jersey, Ohio, Pennsylvania and Wisconsin.

- The stock company experience is based on the latest available data. The Massachusetts experience is that reported in 2935, since its development is more nearly equivalent to that of the figures for other 
I. Massachusetts Statutory Coverage (Stock and Mutual) $\ldots \ldots \ldots \ldots \ldots \ldots \ldots 24$

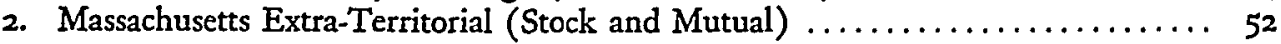

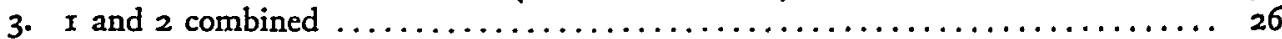

From these figures it appears that the loss cost of statutory coverage has increased in approximately the same ratio as that of full coverage in other states, while the loss cost of extra-territorial coverage ${ }^{24}$ has increased much more rapidly. But even if the increase in cost of full coverage in Massachusetts is compared with that in the cost of full coverage elsewhere the difference is not sufficient to show clearly the responsibility of the Act.

If one turns to the experience on claims, however, there is a marked difference between Massachusetts and other states. Reliable figures are available through 1933 for the experience of stock companies country-wide and in the to states noted above. Using the Massachusetts figures as reported in 1935 the comparative results are as follows:

Private Passenger Cars

Percentage Changes in Claim Cost and Frequency

1927-r933 (inclusive)

Country-wide

except Mass."

Average Cost per Claim .............. + 8.7

Claim Frequency $\ldots \ldots \ldots \ldots \ldots \ldots \ldots \ldots+12.5$

Ten States* Mass. Statutory*"

- Stock company figures.

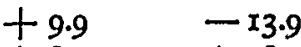

* Stock and mutual.

It appears probable that the Act is responsible for the very great increase in claim frequency as compared with other states. Because of the decrease in the average claim, however, the effect on average cost per car has not been so great as might have been expected. It should be noted that before the taking effect of the Act claim frequency was higher and average claim cost lower in Massachusetts than elsewhere. From I933 to I935 (inclusive) statutory claim frequently decreased 4 per cent, and average claim cost increased 8 per cent. In 1934 the claim frequency under the Massachusetts statutory and extra-territorial coverages combined was approximately double that experienced by stock companies elsewhere.

Whether the large number of claims is due primarily to fraud, to the general knowledge that all Massachusetts cars are insured, or to other influences, the writer is unable to state. Fraud has been present, but whether it has been on a more extensive scale in proportion to the insurance available than in other states is

states than would be the experience as reported in I936. No combined stock and mutual figures for territories outside Massachusetts are available for years previous to 1930 . The following qualifications should be noted: (1) Massachusetts average costs do not include allocated loss expense, others do; (2) the distribution of cars by types (i.e. by rate groups) varies from year to year; (3) the distribution of cars varics between territories; (4) in Massachusetts the policy year is the calendar year; elsewhere experience on policies written in a given year is credited to that year.

${ }^{24}$ Coverage elsewhere than on the ways of Massachusetts. 
problematical. Both the public and attorneys and doctors are well aware of the existence of the insurance, and that fact has probably led to many claims which would not otherwise have been made. Frequent complaint is also heard that much damage to property by automobiles is paid for through the invention or exaggeration of bodily injury claims where there is no property damage liability insurance. ${ }^{25}$

\section{Adequacy of Rates}

Since the Act took effect the premium rates fixed by the Commissioner of Insurance have been inadequate to meet the losses and expenses of the stock companies whose disbursements they were supposed to cover with a margin of 2.5 per cent for profit. The total provision for losses has been inadequate to cover the losses of stock companies and mutual companies combined. Mutuals have, largely through economies in expenses, paid dividends to their policyholders, which, the law requires, shall be based on the segregated experience under the Act. The mutual writing the largest volume of statutory premiums has regularly paid 20 per cent. The dividends of others have varied from o to 35 per cent. The latter figure was paid by a small company in a special situation and is in no way indicative of participating possibilities in general.

The following table indicates the relationship of losses under the Act and of the provision for losses from 1927 to 1935 inclusive:

Excess of Losses Over Provision in Rates-Statutory Coverage (All Classes of Motor Vehicles)

\begin{tabular}{|c|c|c|c|c|}
\hline Year & $\begin{array}{l}\text { Incurred } \\
\text { Losses }\end{array}$ & $\begin{array}{l}\text { Provision for } \\
\text { losses in rates }\end{array}$ & Excess & $\begin{array}{c}\text { Percentage } \\
\text { Excess }\end{array}$ \\
\hline $1927 \ldots \ldots$ & $\$ \mathrm{Ir}, 947,556$ & $\$ 9,938,048$ & $\$ 2,009,508$ & 20 \\
\hline I928. . & $13,026,164$ & $9,885,803$ & $3,140,361$ & 32 \\
\hline rg29............. & $14,608,307$ & $12,574, I_{20}$ & $2,034,187$ & 16 \\
\hline 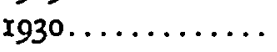 & $x 6,758,287$ & $13,786,15^{8}$ & $2,972,129$ & 22 \\
\hline r931........... & I6,I92,974 & $14,582,162$ & $\mathrm{I}, 6 \mathrm{I0}, 8 \mathrm{I2}$ & II \\
\hline I932 $\ldots \ldots \ldots \ldots$ & $14,914,847$ & $15,361,225$ & $446,37^{8 *}$ & $3^{*}$ \\
\hline I933............ & $15,470,500$ & $14,483,539$ & 986,961 & 7 \\
\hline I934 $\ldots \ldots \ldots \ldots$ & $17,862,124$ & $15,024,593$ & $2,837,531$ & 19 \\
\hline I $935 \ldots \ldots \ldots \ldots$ & $16,669,293$ & $15,584,268$ & $1,085,025$ & 7 \\
\hline Totals. & $\$ 137,450,052$ & $\$ \mathrm{I} 2 \mathrm{x}, 2 \mathrm{\pi}, 9,9 \mathrm{r} 6$ & $\$ 16,230,136$ & I3 \\
\hline
\end{tabular}

- Provision for losses exceeded losses.

During the nine years for which data are available losses for all carriers have exceeded the provision made for them in the established rates by $\$ 16,230,136$ or 13 per cent.

Allowance for expenses and profit in the rates is intended to be sufficient for the needs of stock companies. Actual expenses have exceeded the allowance in all years, as is indicated in the following table.

\footnotetext{
The problem of court congestion is discussed elsewhere in this volume. See Carpenter, Compulsory Motor Vehicle Insturance and Court Congestion in Massachusetts, infra, p. 554.
} 


\begin{tabular}{|c|c|c|c|c|c|}
\hline \multirow[b]{2}{*}{ Year } & \multirow{2}{*}{$\begin{array}{l}\text { Loadings } \\
\text { Allowed by } \\
\text { Commissioner } \\
\text { (including } \\
2.5 \% \text { for profit) }\end{array}$} & \multicolumn{3}{|c|}{$\begin{array}{c}\text { Expense RAtios } \\
\text { (All Classes of Motor Vehicles) }\end{array}$} & \multirow[b]{2}{*}{$\begin{array}{l}\text { Stock Companies } \\
\text { Excess Percentage }\end{array}$} \\
\hline & & $\begin{array}{c}\text { Stock } \\
\text { Companies }\end{array}$ & $\begin{array}{c}\text { INcurs } \\
\text { Mutual } \\
\text { Companies }\end{array}$ & Total & \\
\hline 1927. & $\ldots \quad 40.2$ & 42.65 & 39.65 & $4 x .65$ & 6.1 \\
\hline I928. & .. 40.2 & 42.04 & $35 \cdot 4$ & 39.89 & 4.6 \\
\hline $1929 . \ldots \ldots \ldots$ & .. 34.5 & $3^{8.87}$ & 36.08 & $3^{8.16}$ & 12.7 \\
\hline 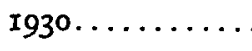 & .. 35.5 & 39.02 & 32.02 & 37.20 & 9.9 \\
\hline 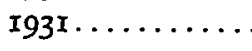 & .. 35.5 & $37 \cdot 91$ & $34 \cdot 32$ & 37.09 & 6.8 \\
\hline $1932 \ldots \ldots \ldots \ldots$ & .. 35.5 & 36.54 & 29.21 & 34.62 & 2.9 \\
\hline x $933 \ldots \ldots \ldots$ & $\cdots \quad 36$. & $37 \cdot 18$ & 27.49 & $34 \cdot 4^{2}$ & $3 \cdot 3$ \\
\hline $1934 \ldots \ldots \ldots \ldots$ & $\cdots \quad 36$. & $3^{6.89}$ & 26.48 & 33.65 & 2.5 \\
\hline 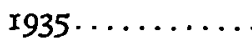 & $\ldots \quad 3^{6}$ & 36.73 & 26.37 & 33.44 & 2.0 \\
\hline
\end{tabular}

For the five-year period, I93 to 1935, the excess of losses and actual expenses of all companies over premiums was $\$ 5,107,858$. If all of the companies had incurred expenses at the actual ratio experienced by the stock companies the excess would have been $\$ 7,954,846$. To provide sufficient funds for actual losses, expenses at the stockcompany ratio, and 2.5 per cent profit would have required $\$$ ro,905,888 in additional premiums or an increase of slightly over 9 per cent of the premiums actually earned.

It is clear that the rates have not been adequate, as required by the Act, and that the stock companies have transacted this business at a loss. ${ }^{20}$

In establishing rates for 1937 the Commissioner of Insurance set a level for statutory coverage approximately ro per cent below that recommended by the companies, and approximately 7 per cent below the 1936 level. He based his rates on the average experience for the five-year period I93I to I935, reducing the incurred losses reported by the companies to allow for what he considered to be unduly high reserves for outstanding losses. The stock companies claim that the rates will again be inadequate for 1937 , even though the 1935 experience shows a lower average loss cost per car than was experienced in 1934. The actuary of the mutual writing the largest volume of Massachusetts business testified before the Commissioner that, under the proposed (and later established) 937 rates, his company estimated that its dividend would be ro per cent instead of the 20 per cent previously paid. The level of rates recommended by the companies for 1937 was based on the experience of I 934 and I 935 and a loading of 37.21 per cent. It is their contention that their reserves are not over-estimated, as evidence of which they point to previous underestimates by the Commissioner's office.

\footnotetext{
${ }^{20}$ It is frequently asserted or implied that the operation of the Act has led to the insolvency or withdrawal from the state of various companies. Several mutuals were organized during the early years of the Act, and quite promptly were placed in receivership, largely because of mismanagement. Otherwise a study of the volume of premiums written fails either to show any unusual change of policy, or any cases of insolvency, which could be attributed to the Act.
} 


\section{Merit Rating}

It has frequently been urged that some plan of merit rating should be adopted as a reward to careful drivers or as a penalty on careless drivers. In response to a resolution of the legislature the Commissioner of Insurance submitted a special report ${ }^{27}$ on that subject. He expressed the opinion that

the adoption of either the merit or the demerit rating plan in any form would serve only to increase the costs payable by motor vehicle owners for or in connection with their compulsory liability insurance, and further to complicate the operation of that law for nearly a million persons affected by it.

This increased cost and complication might possibly be justified ... . if there were any reasonable grounds upon which to base an expectation that such a plan would ultimately effect a decrease in the amount of the compensable claims and a consequent reduction in the premium charges by stimulating the careful operation of motor vehicles. That there are no such grounds seems evident. This seems to be attested by the fact that neither the merit nor the demerit rating plan has in other States been sufficiently, if at all, effective to control motor vehicle accidents so that the compensable losses were decreased. The adoption of either plan would in the light of the experience now available be an experiment that would prove not only expensive but highly unsatisfactory.

\section{Board of Appeai}

If an insurer refuses to issue, or give notice of cancellation of statutory coverage, the insured may complain to the Board of Appeal, which is made up of the Commissioner of Insurance or his representative, the Registrar of Motor Vehicles or his representative, and an Assistant Attorney-General. In the case of cancellation such a complaint operates to continue the statutory coverage pending the results of the complaint, but not beyond its expiration date.

"The complaint may allege that a cancellation is invalid, or improper and unreasonable or both, or that a refusal . . . is improper and unreasonable. The board shall after due hearing forthwith make a finding in respect to the issue or issues raised by the complainant, and it may also, in any case, make a finding as to whether or not the complainant is a proper and suitable person to whom to issue such a policy. ... The board shall in all cases enter . . . an appropriate order." Appeal from findings and orders of the Board lies to the Superior Court or any of its justices. The decision of the Court or justice shall be final.28

The results of complaints to the Board appear in the following table: ${ }^{29}$

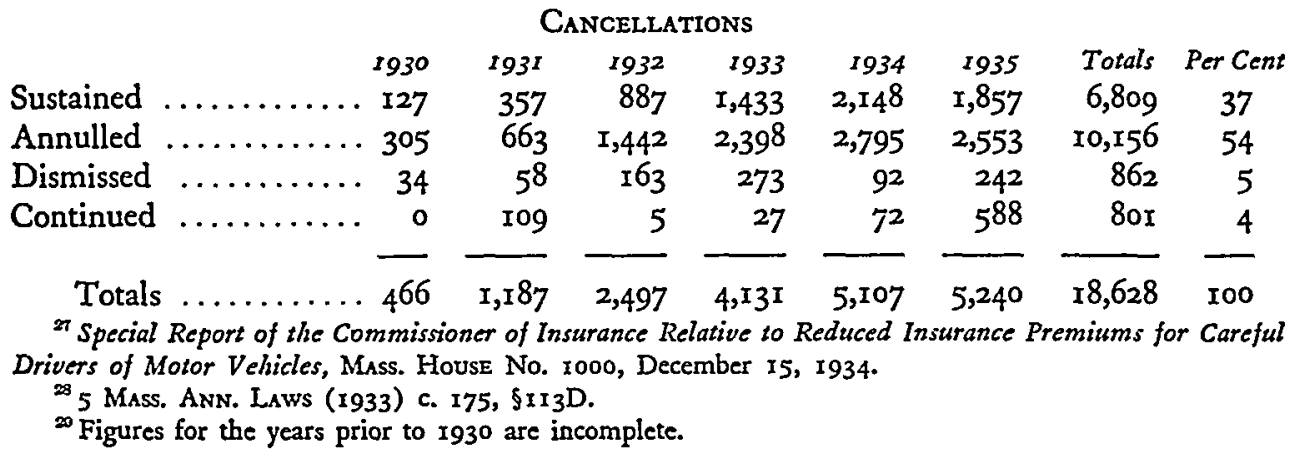




\begin{tabular}{|c|c|c|c|c|c|c|c|c|}
\hline \multicolumn{9}{|c|}{ Refusals } \\
\hline Sustained & 4 & $5^{x}$ & 154 & 287 & 235 & 544 & $\mathbf{r}, 275$ & 34. \\
\hline Not Sustained & 6 & $7^{8}$ & 77 & $x 28$ & 87 & 197 & 573 & 15 \\
\hline Dismissed & 2 & I26 & I77 & 297 & $34^{\circ}$ & 986 & $x, 928$ & $5^{x}$ \\
\hline Continued...$\ldots \ldots \ldots$ & 0 & 0 & 3 & 0 & 4 & I & 8 & 0 \\
\hline Totals & I2 & 255 & $4 \mathrm{II}$ & $7 \times 2$ & 666 & $I, 728$ & 3,784 & \\
\hline
\end{tabular}

Owing to the method of classification used by the Board, it is rather difficult to draw accurate conclusions from these statistics. For example, 7,49I of the cancellation cases recorded as "annulled," or 40 per cent of the total of such cases, were listed as "reinstated by carrier." While there is no record of the motivation behind reinstatement, it was probably usually due to the carrier anticipating annulment of the cancellation. $\mathrm{r}, 290^{30}$ of the refusal cases recorded as "dismissed," or 34 per cent of the total refusal cases, were listed under "Carrier agrees to issue." Possibly in most of these cases the carrier foresaw defeat. It appears that over the six years carriers continued or issued policies in approximately one-half of the cases brought before the Board. In approximately one-third of the cases the Board sustained the action of the carrier. The remaining cases were disposed of in various ways. In only 52 cases did the Board find the complainant was "not a proper risk."31

The carriers maintain that they issue or continue many policies which would not be on their books if they felt free to underwrite as they chose. There is no means of determining to what extent this is true, and it must be remembered that many undesirable risks are carried in other states for reasons of business policy. It would be instructive to have figures on the experience of carriers with the risks which they are forced to take, but none are available.

Apparently the Board has established no principles on the basis of which findings will be made. Each case is considered on its merits as they appear at the time. From conversations with representatives of the carriers it appears that they are most likely to be sustained in cases involving illegally registered cars, recent criminal records of serious driving offenses, or serious defects in equipment.

\section{The Act and Accidents}

It has frequently been contended that the Act has increased accidents in Massachusetts. The argument in support of this contention rests in many cases on the sincere conviction that persons who are required to carry insurance are made more careless than they would be without insurance. It is the equally sincere conviction of many (including the writer) that insurance has no appreciable effect on the safety with which these insureds drive.

The increase in fatalities due to motor vehicle accidents in the state has frequently been cited as evidence of the effect of the Act. But this increase is only part of a

${ }^{30} 84$ for I93I estimated.

st No figures are available to show the results of appeals to the Superior Court. The general impression is that such appeals usually uphold the findings of the Board. 
general increase in motor vehicle fatalities throughout the country. Comparisons with other localities show that the Massachusetts record is better than some, poorer than others, and better than the country as a whole. On a gasoline consumption basis, the motor vehicle fatality rate of 1935 compared with that of 1930 decreased 9 per cent in Massachusetts and increased $\mathbf{2 . 2}$ per cent in the country as a whole. Rhode Island showed a decrease in the same period of 30.9 per cent, while Nevada showed an increase of 52.1 per cent. ${ }^{32}$ Other data show the following percentage change in motor vehicle fatality rates for the period 1926 to $1935:^{33}$ Massachusetts, -32; Maine, +5; New Hampshire, -ro; Vermont, -r; Rhode Island, -60; Connecticut, -26; five New England states other than Massachusetts, -25 . During the same period New York, New Jersey and Pennsylvania combined showed a reduction of 28 per cent.

These and other figures do not indicate that fatal accidents have been either increased or decreased by the operation of the Act.

\section{ConcLusion}

Is the Act a success? It is impossible to answer this question in terms of any criteria which would be generally acceptable. Unquestionably many just claims for damages have been paid which would not otherwise have been met, at least to the same extent. ${ }^{34}$ The Act has largely accomplished its purpose of making motorists in Massachusetts financially responsible. That it does not reach Ioo per cent of the motorists nor cover all injuries makes it no less successful within its scope. It is neither a safety nor a compensation measure. It should be judged on its worth as a financial responsibility law.

The Act has given rise to political difficulties, it has involved insurance companies in underwriting losses, and it may have led to fraud. It is not possible to weigh these two sides of the case, one against the other, with scientific exactness. One's opinion must be based on impressions and ideals.

Nat. SAfety Council, Accident Facts ( 1936 ed.) 67. Other figures are given on pages 44, 45, and 68.77 .

Furnished by Mr. Merwyn A. Kraft. Based on gasoline consumption.

a See Report by the Committee to Study Compensation for Automobile Accidents to the Columbia University Council for Research in the Social Sciences (I932) 75. 